Volume 19 Nomor 1 (2020) 87-96P-ISSN 1411-7673 E-ISSN 2776-5571 DOI: $10.47467 / m k . v 19 i 1.584$

\title{
Penerapan Media Aplikasi Zoom Meeting Dalam Meningkatkan Prestasi Belajar pada Mata Pelajaran Al- Qur'an Hadis Siswa Kelas IX MTs Swasta Al-Washliyah Stabat
}

\author{
Khairil Anwar' ${ }^{1}$, Fauzan Azmi ${ }^{2}$ \\ 1,2 STAI Jam' iyah Mahmudiyah Tanjung Pura Langkat ${ }^{1}$ \\ azmif4210@gmail.com
}

\begin{abstract}
ABSTRAK
Penelitian ini mengangkat permasalahan kurang efektifitas dan efesien dalam menggunakan media pembelajaran Al-qur'an Hadis di masa pandemi saat ini. Pelajaran Al-Quran Hadis dapat dikembangkan melalui aplikasi Zoom Meeting. Tujuan penelitian ini untuk melatih keterampilan membaca Al-Quran secara lisan dan tulisan meningkatkan kemampuan nilai-nilai kualitas keimanan serta pengetahuan keislaman siswa kelas IX MTs Swasta AL-Washliyah Stabat. Penelitian ini merupakan penelitian tindakan kelas (PTK) (Syahbuddin AR:2012). dengan pelaksanaan model penelitian tindakan dalam bentuk spiral dan siklus yang satu ke siklus yang berikutnya dari prosedur pengebangan (Elfanany, 2013:58) yang mempunyai empat tahap. Adapun prosedur penelitian ini dilakukan yaitu perencanaan, tindakan, pengamatan, dan refleksi. Penelitian ini menghabiskan waktu selama 5 bulan, pada bulan Januari s/d Juni 2020. Subjek dalam penelitian ini adalah siswa kelas IX MTs Swasta AL-Washliyah Stabat dengan jumlah siswa 40 orang. Teknik analisis data dalam penelitian ini adalah analisis data kualitatif dan analisis data deskriptif kauntitatif. Teknik pengumpulan data yang digunakan instrumen, wawancara, observasi dan latihan keterampilan self regulation. Hasil penelitian penerapan media aplikasi zoom meeting dalam meningkatkan prestasi belajar dalam pelajaran AlQur'an Hadis pada siswa kelas IX MTs Swasta AL-Washliyah Stabat. Dilihat berdasarkan hasil pada siklus I sampai dengan siklus III mendapatkan hasil Pada siklus I dicapai prosentase ketuntasan sebesar 63,64 \% meningkat 7,8\% dari pra siklus, Pada siklus II dicapai prosentase ketuntasan belajar sebesar 78,8 \% ada kenaikan lagi sebesar $15 \%$ dari siklus I, dan Pada siklus III dicapai ketuntasan belajar sebesar 90,3 \% meningkat dari siklus II. Jadi dari pra siklus sampai dengan siklus III ada kenaikan tingkat sebesar 33,7 \%. Hasil uji dari nilai siswa telah memenuhi Ketuntasan Kriteria Minimum (KKM) yaitu 70 untuk mata pelajaran Al quran Hadis dan telah mencapai klasifikasi sangat efektif dan efisien.
\end{abstract}

Keywords: Kemampuan, Prestasi, Zoom Meeting.

Abstract: This study raises the issue of lack of effectiveness and efficiency in using the Al-Qur'an Hadith learning media during the current pandemic. Al-Quran Hadith lessons can be developed through the Zoom Meeting application. The purpose of this study was to train the skills of reading the Koran orally and in writing to improve the ability of the quality values of faith and Islamic knowledge of class IX students of MTs Swasta AL-Washliyah Stabat. This research is a classroom action research (CAR) (Syahbuddin AR:2012). with the implementation of the action 
research model in the form of a spiral and one cycle to the next from (Elfanany, 2013:58) development procedure which has four stages. The procedures for this research were planning, action, observation, and reflection. This research took 5 months, from January to June 2020. The subjects in this study were grade IX students at Private MTs AL-Washliyah Stabat with a total of 40 students. The data analysis technique in this research is qualitative data analysis and quantitative descriptive data analysis. Data collection techniques used instruments, interviews, observation and self-regulation skills training. The results of the research on the application of the zoom meeting application media in improving learning achievement in Al-Qur'an Hadith lessons in class IX students at Private MTs AL-Washliyah Stabat. Judging based on the results in the first cycle to the third cycle, the results were obtained. In the first cycle, the percentage of completeness was $63.64 \%$, an increase of $7.8 \%$ from the precycle. In the second cycle, the percentage of mastery learning was $78.8 \%$. There was another increase of $15 \%$. from the first cycle, and in the third cycle achieved learning completeness of $90.3 \%$ increased from the second cycle. So from pre-cycle to cycle III there is an increase in the level of 33.7\%. The test results of students' scores have met the Minimum Criteria for Completeness (KKM) which is 70 for Al-Quran Hadith subjects and has achieved a very effective and efficient classification.

Keywords: Capacity Building, cognitive, Zoom Meeting learning

\section{Pendahuluan}

Dimensi yang terkandung dalam konsepsi pendidikan di masa pandemi ini terkait mewabahnya virus covid 19 di indonesia merupakan hal yang melatar belakangi penerapan media online yang menjadi perintis kegiatan belajar secara daring atau jarak jauh sehingga pelaksanaan pembelajaran juga tekena dampak dan sangat berpengaruh dalam situasi kondisi belajar dan mengajar. Artinya, selain penerapan pelajaran jarak jauh namun tingkat efektifitas penerapan media zoom meeting pada pelajaran Al-Quran Hadis perlu diukur sesuai dengan prosedur pembelajaran.

Keahlian yang perlu dimiliki dalam penerapan media zoom meeting pada pelajaran Al-Qur'an Hadis bisa sangat efektif digunakan pada masa pandemi saat ini. Menurut Arends dalam Trianto Pembelajaran Online adalah salah satu pendekatan mengajar yang dirancang khusus untuk menunjang proses belajar siswa yang berkaitan dengan pengetahuan deklaratif dan pengetahuan prosedural yang 
terstruktur dengan baik yang dapat diajarkan dengan pola kegiatan yang bertahap, selangkah demi selangkah (Trianto. $2011: 29$ )

Disinilah perlu mengetahui seberapa besar pemanfaatan aplikasi zoom meeting sebagai media pembelajaran di masa sosial distancing terhadap prestasi belajar siswa karena dikhawatirkan jika pembelajaran hanya mempergunakan metode konvensional ditengah-tengah krisis covid 19 ini maka akan mengakibatkan menurunnya prestasi belajar siswa. Oleh sebab itu, salah satu solusi terbaik untuk meningkatkan prestasi belajar siswa yaitu dengan menerapkan sistem belajar jarak jauh melalui aplikasi aplikasi zoom meeting.

Jadi dapat disimpulkan bahwa penerapan sistem belajar online tersebut merupakan produk yang baru dan merupakan inovasi pembelajaran yang dapat dilaksanakan secara berkesinambungan. Namun efektifitas dan efesiensinya belum dapat menyentuh pada prestasi belajar siswa dalam kegiatan belajar.

Seiring dengan perkembangan teknologi informasi dan komunikasi yang semakin pesat, kebutuhan akan suatu konsep dan mekanisme belajar mengajar berbasis Teknologi dan informasi tidak terelakkan lagi. Konsep belajar tersebut disebut dengan istilah e-learning (elektronik learning) yaitu belajar dengan sistem online memanfaatkan media internet. Saat ini konsep belajar online sudah banyak diterima oleh pihak sekolah maupun masyarakat secara umum dengan terbukti bahwa banyak orang yang sudah tidak asing mempergunakan smart phone yang berbasis teknologi terbaru (Suyuti, 2015).

Salah satu keunggulan dari pembelajaran Online adalah adanya fokus akademik merupakan prioritas pemilihan tugas-tugas yang harus dilakukan siswa selama pembelajaran, aktivitas akademik harus ditekankan (Yamin, 2010:37)

Fathurrohman menjelaskan "Pembelajaran Online dikembangkan dari teori pembelajaran berkarakteristik behavioristik yaitu teori-teori tingkah laku yang telah memberikan kontribusi signifikan terhadap Pembelajaran Online. Pada dasarnya konkesuensi model ini yaitu sebagai berikut :

1) Memungkinkan siswa untuk saling berbagi informasi pada waktu yang bersamaan.

2) Dapat diterapkan untuk beberapa mata pelajaran seperti ilmu pengetahuan sosial, agama dan bahasa serta bidang studi lainnya. Bahan yang sangat cocok untuk model ini yaitu pembelajaran yang menggukan tehnik pertukaran pikiran dan informasi antar siswa.

Dapat diterapkan untuk semua tingkatan kelas. 
Berdasarkan uraian diatas dapat disimpulkan bahwa Program pembelajaran online ini efektif dimulai dengan perencanaan dan terfokus pada kebutuhan bahan pelajaran dan kebutuhan siswa terhadap materi pelajaran. Teknologi yang tepat hanya dapat diseleksi ketika elemen-elemen ini dimengerti secara detail. Faktanya kesuksesan program pembelajaran online berhubungan dengan usaha yang konsisten dan terintegrasi dari siswa, madrasah, fasilitator, staf penunjang, sarana dan prasarana.

Berdasarkan hasil wawancara dengan guru bidang studi Al-Qur'an hadis di kelas IX yang menerangkan bahwa guru bidang studi Al-Qur'an Hadis sudah menerapkan sistem belajar online atau daring semenjak diberlakukannya sistem belajar di rumah berdasarkan instruksi pemerintah dalam menyikapi dampak pandemi covid 19 pada tahun 2020. Oleh sebab itu, peneliti mendapatkan data awal bahwa penerapan sistem belajar online tersebut merupakan produk yang baru dan merupakan inovasi pembelajaran yang dapat dilaksanakan secara berkesinambungan. Namun efektifitas dan efesiensinya belum dapat menyentuh pada prestasi belajar siswa dalam kegiatan belajar.

Pembelajaran jarak jauh merupakan pembelajaran yang dalam penerapannya menggunakan media atau jasa bantuan perangkat elektronik yang mendukung program Audio, video dan peranti lunak yang bisa dikombinasikan menjadi satu perangkat sehingga pembelajaran dengan menggunakan bantuan perangkat ini disebut dengan istilah belajar jarak jauh yakni antara tenaga pengajar tidak bertatapan langsung dengan siswa (Faturrohman, 2015).

Berdasarkan hal tersebut, pembelajaran jarak jauh memerlukan suatu alat pembelajaran agar prestasi siswa dalam belajar dapat terwujud dengan tumbuhnya kemampuan belajar diri siswa. Berdasarkan Permendikbud No.87 tahun 2013 perangkat pembelajaran yang komprehensif mencakup rencana pelaksanaan pembelajaran, bahan ajar, media pembelajaran, evaluasi, dan lembar kerja siswa. Oleh karena itu dalam proses pembelajaran, salah satunya memerlukan media pembelajaran.

Dalam penelitian ini, peneliti mencoba menerapkan media zoom meeting berupa tindakan kelas yang dilaksanakan sebagai strategi pemecahan masalah dengan memanfaatkan tindakan nyata kemudian melakukan refkelsi terhadap hasil tindakan. Hasil tindakan dan refleksi tersebut dijadikan sebagai langkah pemilihan tindakan berikutnya sesuai dengan permasalahan yang dihadapi Untuk mengetahui pembelajaran jarak jauh melalui aplikasi zoom meeting pada mata pelajaran Al- 
Qur'an Hadis sekaligus mengetahui prestasi belajar siswa kelas IX MTs Swasta AlWashliyah Stabat

Berdasarkan uraian beberapa permasalahan diatas, peneliti menerapkan media zoom meeting guna meningkatkan prestasi belajar siswa dan dapat digunakan oleh guru pelajaran AL-Quran Hadis Dengan menggunakan media zoom meeting sangat banyak manfaatnya, siswa mampu meningkatkan prestasi belajar, menjalankan proses pembelajaran dengan efektif dan efisien.

\section{Metode}

Penelitian ini menggunakan pendekatan tindakan kelas (Research \& Develovment). Menurut Syahbuddin model penelitian yang digunakan model penelitian tindakan dalam bentuk spiral dan siklus yang satu ke siklus yang berikutnya. meliputi planning (perencanaan), action (tindakan), observation (pengamatan) dan reflection (refleksi) (Hidayat, 2017). Teknik pengumpulan data dalam penelitian ini meliputi instrumen, wawancara, dan observasi. Subjek dalam penelitian tindakan kelas yang dilakukan oleh peneliti adalah seluruh siswa/i Kelas IX MTs. Swasta Al-Washliyah yang berjumlah 40 orang siswa. Adapun partisipan yang turut membantu pelaksanaan penelitian tindakan kelas ini yaitu kepala Madrasah Tsanawiyah Swasta Al-Washliyah.

\section{Hasil dan Pembahasan}

Penerapan media aplikasi zoom meeting untuk siswa dilaksanakan sesuai dengan prosedur dari Syahbuddin AR (Syahbuddin, 2012:42), dengan model penelitian tindakan dalam bentuk spiral dan siklus yang satu ke siklus yang berikutnya. meliputi. Hal ini menggunakan empat langkah prosedur penelitian yaitu: planning (perencanaan), action (tindakan), observation (pengamatan) dan reflection (refleksi).

1. Perencanaan

Langkah awal berdasarkan pelaksanaan dilapangan peneliti membuat LAS yang berisi materi ajar yang akan digunakan pada saat tindakan berlangsung. Selain itu, peneliti juga menyusun berbagai instrument penelitian dan tes di akhir siklus. Bersama guru kolaborator, peneliti mendiskusikan pelaksanaan RPP yang akan dilaksanakan dan mendistribusikan cara penilaian observasi kemampuan pemahaman belajar siswa di dalam kelas.

\section{Nilai Siswa Pra Siklus}




\begin{tabular}{|c|c|c|c|}
\hline No. & Nilai Siswa & Jumlah & Prosentase \\
\hline 1 & $<39$ & 0 & $0 \%$ \\
\hline 2 & $40-49$ & 16 & $43.2 \%$ \\
\hline 3 & $50-59$ & 4 & $10,8 \%$ \\
\hline 4 & $60-69$ & 6 & $16,2 \%$ \\
\hline 5 & $70-79$ & 9 & $24,3 \%$ \\
\hline 6 & $80-89$ & 2 & $5,4 \%$ \\
\hline 7 & $90-100$ & 0 & $0 \%$ \\
\hline & Jumlah & 37 & $100 \%$ \\
\hline
\end{tabular}

Data diatas dapat disimpulkan siswa yang telah tuntas dengan KKM 70 sebanyak 11 siswa atas 29,8 \% dan yang belum tuntas sebanyak 26 siswa atau 70,2 \% dari jumlah siswa dikelas IX MTs. Swasta Al-Washliyah Stabat. Nilai rata-rata kelasnya adalah 56,55.

2. Tindakan

Tahap pelaksanaan siklus I terdiri dari empat pertemuan ditambah satu pertemuan untuk tes akhir siklus.

Nilai Prestasi Pemahaman Siswa pada Siklus II

\begin{tabular}{|c|c|c|c|}
\hline No. & Nilai Siswa & Jumlah & Prosentase \\
\hline 1 & $<39$ & 0 & $0 \%$ \\
\hline 2 & $40-49$ & 0 & $0 \%$ \\
\hline 3 & $50-59$ & 0 & $0 \%$ \\
\hline 4 & $60-69$ & 8 & $21,6 \%$ \\
\hline 5 & $70-79$ & 17 & $21,6 \%$ \\
\hline 6 & $80-89$ & 4 & $45,9 \%$ \\
\hline 7 & $90-100$ & 37 & $10,8 \%$ \\
\hline
\end{tabular}


Nilai individual siswa meningkat dari siklus I. Tidak ada siswa yang mendapat nilai kurang dari 50, dan hanya 8 atau 21,6 \% yang belum tuntas. Nilai rata-rata kelasnya adalah 78,8 berarti ada kenaikan 15,16 \% dari siklus I. Berdasarkan pengamatan peneliti terhadap delapan siswa yang belum tuntas, dua diantaranya bukanlah siswa yang memiliki intelegensi rendah akan tetapi memiliki sifat cuek, kurang tanggung jawab dan kurang taat dalam peraturan. Sedangkan dua di antaranya memiliki intelegensi sedang dan rendah.

Nilai Prestasi Pemahaman Siswa pada Siklus III

\begin{tabular}{|c|c|c|c|}
\hline No. & Nilai Siswa & Jumlah & Prosentase \\
\hline 1 & $<39$ & 0 & $0 \%$ \\
\hline 2 & $40-49$ & 0 & $0 \%$ \\
\hline 3 & $50-59$ & 0 & $0 \%$ \\
\hline 4 & $60-69$ & 0 & $0 \%$ \\
\hline 5 & $70-79$ & 4 & $10,8 \%$ \\
\hline 6 & $80-89$ & 13 & $35,1 \%$ \\
\hline 7 & $90-100$ & 20 & $54,1 \%$ \\
\hline & Jumlah & 37 & $100 \%$ \\
\hline
\end{tabular}

Nilai yang diperoleh siswa pada siklus III mengalami peningkatan dari siklus sebelumnya yaitu siklus II. Pada siklus III semua siswa memperoleh nilai di atas KKM yang telah ditetapkan. Jadi secara keseluruhan nilai siswa mengalami penuntasan tanpa terkecuali.

\section{Pengamatan}

Berdasarkan pemaparan pada hasil penelitian dari mulai pra siklus sampai pada siklus ke III dalam penelitian diatas maka data nilai prestasi belajar dalam memahami materi Pemahaman surat pendek $\mathrm{Al}$ quranpada mata pelajaran $\mathrm{Al}$ quran Hadis secara keseluruhan dapat dilihat pada gambar berikut : 
Ketuntasan Siswa dari Pra Siklus Sampai Dengan Siklus III

\section{Siklus}

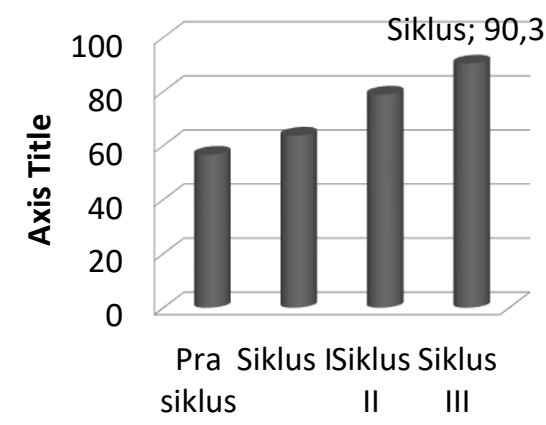

Dari hasil ketuntasan diatas dapat di jelaskan pada pra siklus 56,66 \% siswa yang tuntas, pada siklus I meningkat menjadi $63,64 \%$ siswa yang tuntas dalam kegiatan pembelajaran $\mathrm{Al}$ quran Hadis pada materi Pemahaman surat pendek $\mathrm{Al}$ quran . Pada siklus II tingkat ketuntasan siswa dalam belajar Al quran Hadis yaitu 78,8 \% dari kelas IX MTs. Swasta Al-Washliyah Stabat. Kemudian dianalisis dari siklus III ketuntasan siswa mencapai 90,3\%.

\section{Rutinitas Siswa dari Siklus I sampai dengan siklus III}

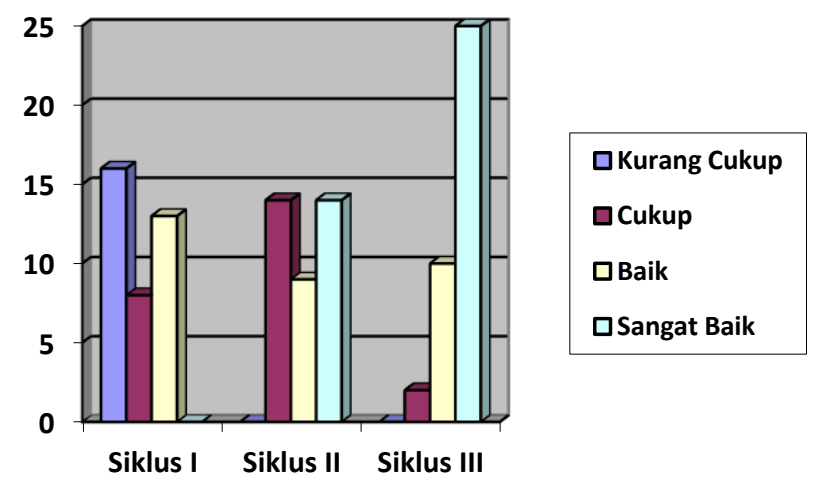

Untuk menambah keabsahan data yang didapat dari hasil analisis data secara kuanitatif maka peneliti juga menambahkan data secara kualitatif dalam bentuk melakukan observasi terhadap siswa untuk mengetahui rutinitas dan kerjasama siswa dalam pembelajaran Al quran Hadis dengan menggunakan sistem bekerjasama dalam satu kelompok. 


\section{Rutinitas Pemahaman Siswa dari Siklus I sampai dengan siklus III}

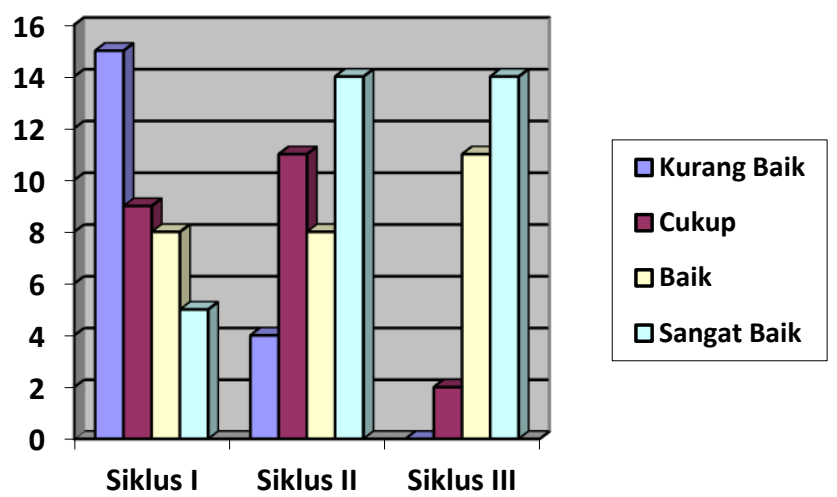

Prestasi siswa dalam mengulangi dan mempelajarai materi surat pendek Al quran tidak hanya dipengaruhi dan ditentukan oleh penggunaan suatu metode atau strategi pembelajaran saja akan tetapi juga dipengaruhi oleh beberapa faktor diantaranya adalah faktor bakat, minat, tingkat pengetahuan, karakteristik belajar siswa dan juga ketepatan metode pembelajaran yang digunakan oleh guru dalam kegiatan belajar dan mengajar. Sebagai contoh ditemukannya siswa yang kurang aktif dalam bekerja sama di kelompok diskusi namun siswa tersebut tetap mendapat nilai diatas KKM yang telah ditetapkan.

4. Refleksi

Adapun faktor yang mendukung dan faktor yang menghambat dalam pelaksanaan penelitian ini yaitu sebagai berikut :

Dalam pelaksanaan penelitian tentang upaya yang dilakukan untuk meningkatkan kemampuan siswa memahami materi Pemahaman surat pendek $\mathrm{Al}$ quran pada mata pelajaran Al quran Hadis Kelas IX MTs. Swasta Al-Washliyah Stabat tentu peneliti menemukan berbagai faktor penghambat pelaksanaan pembelajaran dan penelitian namun peneliti meyakini bahwa faktor penghambat tentu dibarengi dengan faktor pendukung. Pada pelaksanaan penelitian faktor-faktor penghambat dan pendukung sangat bervariasi terutama pada pelaksanaan penelitian di masingmasing siklus.

Jadi dapat disimpulkan bahwa Penerapan media aplikasi zoom meeting sangat membantu siswa maupun guru Al-Qur'an Hadis untuk meningkatkan prestasi 
belajar siswa. Dengan media tersebut juga membantu siswa untuk belajar secara mandiri dan membantu meningkatkan prestasi belajarnya.

\section{Simpulan}

Kesimpulan hasil analisis data dan pembahasan adalah Penggunaan Pembelajaran Jarak Jauh dapat meningkatkan kemampuan Pemahaman pada mata pelajaran Al quran Hadis pada siswa kelas IX MTs. Swasta Al-Washliyah Stabat, sesuai dengan nilai ketuntasan siswa yang diperoleh pada siklus I sampai dengan siklus III yaitu sebagai berikut : 1) Pada pra siklus ketuntasan mencapai 56,55 \% siswa. 2)Pada siklus I dicapai prosentase ketuntasan sebesar 63,64 \% meningkat 7,8\% dari pra siklus. 3)Pada siklus II dicapai prosentase ketuntasan belajar sebesar 78,8 \% ada kenaikan lagi sebesar $15 \%$ dari siklus I. 4)Pada siklus III dicapai ketuntasan belajar sebesar 90,3 \% meningkat dari siklus II. Jadi dari pra siklus sampai dengan siklus III ada kenaikan tingkat sebesar $33,7 \%$.

\section{Daftar Pustaka}

Aditya, N. 2012. Kamus Lengkap Bahasa Indonesia. Surabaya: Usaha Jaya.

Ahda Bina. 2016. Jurus Jitu Menghafal Al-Quran. Jakarta: Mutiara Ilmu.

As-Suyuti. J. 2015. Terjemah Tafsir Jalalain 2. Surabaya: Sinar Baru Algesindo.

Damayanti, D. 2014. Panduan Implementasi Pendidikan Karakter Di Sekolah, Jakarta: Araska.

Elfanany, Burhan. 2013. Penelitian Tindakan Kelas. Jakarta: Araska.

Faturrohman. 2015. Model-Model Pembelajaran Inovatif. Jakarta: Ar-Ruzz Media.

Hidayat M. Arif. 2017. The Methodology Of Edicational Research, Medan: Perdana Publishing.

Muhibinsyah. 2017. Psikologi Pendidikan. Jakarta: Remaja Rosdakarya

Syahbuddin AR. 2012. Pedoman dan Materi Pelatihan Penelitian Tindakan Kelas. Bandung: Universal Offiset.

Trianto. 2011. Mendesain Model Pembelajaran Inovatif, Jakarta: Kencana Prenada Media.

Yamin, M. 2010. Strategi Pembelajaran Berbasis Kompetensi, Jakarta:Gaung Persada Press. 